\title{
The Other Thys. An examination of the work of Gysbrecht Thys: a painter of 'devotions, poetries and landscapes' and a collaborator with Joris van Son
}

Resumen: El pintor flamenco Gysbrecht Thys (también escrito Thijs, Thyssen o Tijssens) (1617- h. 1684) ha sido durante siglos confundido con varios de sus homónimos. Aunque su identidad fue desentramada en 1996 en dos artículos fundamentales, ninguna obra suya había salido a la luz hasta hoy. Las pinturas estudiadas en el presente artículo, primeras aportaciones a la producción de Gysbrecht Thys, ayudan a definir la personalidad artística de un pintor olvidado. Considerando las composiciones de sus pinturas, sus fuentes de inspiración formales y literarias, y las influencias que forjan su estilo, el pintor se revela versátil, con un cierto grado de cultura clásica adquirido en Italia y probablemente en contacto con círculos religiosos eruditos en Amberes. Su participación en una Guirnalda de flores y frutas de Joris van Son permite un excurso en la producción de éste y su probable colaboración con Jan van Balen entre otros; en busca de un mejor conocimiento de la producción de algunos pintores poco estudiados de la escuela de Amberes del siglo XVII.

Palabras clave: Pintura flamenca; guirnaldas de flores en el art; Thijs; Thyssen; Tijssens; Jan van Balen; Amberes siglo XVII; Tiziano Bacanal; Sint-Bartholomeuskerk Merksem; Investigación

Abstract: The Flemish painter Gysbrecht Thys (also spelled Thijs, Thyssen or Tijssens) (1617- ca. 1684), has for centuries been mistaken for several of his namesakes. Although his identity was clarified in 1996 by two essential articles, none of his works have previously surfaced until today. The paintings studied in the present paper, which are the first addition to Gysbrecht Thys' œuvre, help to define the artistic personality of a previously neglected painter. Given to consider the painting's compositions, their formal and literary sources of inspiration, and the influences that

${ }^{1}$ https://orcid.org/0000-0001-8564-9703

(C) 2017 Philostrato. Revista de Historia y Arte 
make-up his style; Thys reveals his versatility, a certain degree of classical culture from his time in Italy, and probable contacts with erudite religious circles in Antwerp. Further Thys' participation in a Garland of fruit and flowers by Joris van Son, allows for an excursus on the latter's production and on his probable collaboration with Jan van Balen among others; leading to a greater understanding of several less studied masters from the Antwerp School in the $17^{\text {th }}$ century.

Key words: Flemish painting; flowers garland in Art; Thijs; Thyssen; Tijssens; Jan van Balen; Antwerp; 17th century; Titian and Bacchanal; Sint-Bartholomeuskerk Merksem; Art History Research

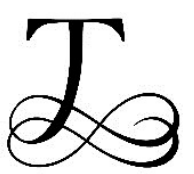

he history of art presents numerous cases of anonymous artists whose work has been identified and studied on the basis of stylistic evidence alone. Given the lack of any documentation that allows for a defined style to be associated with a specific name, art historians are obliged to give these artists generic names in the hope that the chance appearance of some concrete proof, such as a signature or a related document, will reveal the artist's true identity. In contrast, on occasions we know the name of an artist but have no information on his artistic personality due to a lack of identified works. Documents associated with the Guild of Saint Luke in Antwerp are filled with the names of painters about whom very little or nothing is known. On some occasions an artist's biography and the documentation of his works have survived, but it has not been possible to attribute a single work to them. This is the case with the present painter, who has been the victim of a fusion of identities by art theoreticians.

For many years the name of Gysbrecht Thys, also spelled Thijs, Thyssen and Tijssens (1617-ca.1684), was confused with his homonym Peter Thys (1624-1677), a better known painter and a follower of Anthony van Dyck ${ }^{2}$. In the $18^{\text {th }}$ century Arnold Houbraken, Campo Weyerman and Jean Baptiste

\footnotetext{
2 On Peter Thijs see M. L. Hairs, Dans le sillage de Rubens: les peintres d'histoire anversois au XVIIe siècle, (Liège, 1977), pp. 265-276; D. Maufort, De Antwerpsche kunstschilder Peeter Thijs de Oude. Een enadering aan de hand van zjn historiestukken, Verhandeling van licenciaat, prom. H. Vlieghe, (Leuven, Katholieke Universiteit, 1986); A. Balis, "Pieter Thys, Marten Pepyn und der dritte "Pseudo-Boeckhorst"', in: Jan Boeckhorst, Maler der Rubenszeit, (Freren, 1990), pp. 98-108; H. Vlieghe, "Thoughts on Van Dyck's Early Fame and Influence in Flanders", in Van Dyck 350, Studies in the History of Art, Center for Advanced Study in the Visual Arts, Susan J. Barnes and Arthur K. Wheelock (ed.), vol. 46, (Washington, 1994), p. 211-215; D. Maufort, "Een zelfportret van Peter Thijs de Oude (1624-1677) in de Koninklijke Musea voor Schone Kunsten van België", Bulletin Koninklijke Musea voor schone Kunsten van België (1994/1-4 1995/1-4), pp. 103-124; R. Tomić, "Prijedlog za Pietera Thysa: « Pranje nogu u Bribiru », Peristil, Zbornik radova za poviejest umjetnosti 38 (1995), pp. 117-120; J. Douglas Stewart, "Pieter Thys (1624-1677). Recovering a scarcely known Antwerp painter", Apollo (Feb. 1997), pp. 37-43; J. Douglas Stewart, "Thomas Willeboirts Bosschaert and Pieter Thys: a tale of two tangled Antwerp painters; with an Excursus on Van Dyck's St. Felix of Cantalice", in Van Dyck 1599-1999: Conjectures and Refutations, H. Vlieghe (ed.), (Brussels, 2001), pp. 271-288; D. Maufort, "Une Vanité avec les trois Parques au Musée d'Art et d'Histoire de Genève et l'oeuvre du peintre anversois Peter Thijs (1624-1677)", Genava 49 (2001), pp. 315; K. Daemen-de Gelder and J.P. Vander Motten, "Peeter Thijs (1624-77) - an Antwerp Portraitist under the Patronage of William Frederick of Nassau-Dietz (1613-64", Zeitschrift für Kunstgeschichte 72 (2009), pp. 128-131; J. Sanzsalazar, "Una nueva pintura de Peter Thijs identificada en la colegiata de Santa Gertrudis de Nivelles (Valonia)", Archivo Español de Arte 82 (2009), no. 325, pp. 79-86; J. Sanzsalazar, "Peter Thijs: A preparatory drawing identified for The marthyrdom of saint Benedict with saint Felix of Cantalice", Delineavit et Sculpsit 33 (July 2010), pp. 25-29.
} 
Descamps introduced this confusion that has survived over time ${ }^{3}$, despite the appearance of two publications on this issue that are not sufficiently well known. I refer to the documents published by Erik Duverger and Danielle Maufort in 1996, which offered the first information on Gysbrecht Thys' life and documentation of his work, thus distinguishing him from Peter Thys, the 'painter of portraits' referred to in earlier art-historical texts. Gysbrecht was a first cousin of Peter, both of them descendants of a wealthy family of bakers ${ }^{4}$. Their uncle, Joost Thys, was a painter who was trained in the studio of Hendrick van Balen from 1602 onwards $^{5}$, but of whom nothing else is known. This quid pro quo is complicated by the existence of other Antwerp painters with the same surname, who were descendants of the art dealer Augustijn Tijssens the Elder (1597-1692) and who seem not to be related to the former family ${ }^{6}$ : Augustijn Tijssens the Younger (1623-1675), a painter of landscapes and mythological scenes in the style of Nicolas Berchem ${ }^{7}$; Jan Baptist Tijssens the Elder (1638-1689/1709), active in The Hague (1669), Rome (1681) and Dublin (1684) but with no known work ${ }^{8}$; Jan Baptist Tijssens the Younger (1657-after 1723), a pupil of Anton Goubau who painted genre scenes in the style of David Teniers and still lifes in the manner of Frans Snyders $^{9}$; and Jacomo Tijssens (1660-1723), a portrait and landscape painter of whom no works have been identified ${ }^{10}$. The result is a complex web that Duverger and Maufort have been admirably untangling with their publication of documentary evidence.

With regard to Gysbrecht Thys, we know now that he was baptised in 1617 in the church of Saint James the Greater in Antwerp ${ }^{11}$ and that at the age of twelve he entered the studio of a little-known painter named Jacques van Bemden, as recorded in the documents of the painters' guild of $1629-30^{12}$.

\footnotetext{
${ }^{3}$ A. Houbraken, De groote schouburgh der Nederlantsche konstschilders en schilderessen, Den Haag, vol. 2, 1719, p. 144; J. C. Weyerman, De levens beschrijvingen der Nederlandse konstchilders en konstschilderessen..., (Gravenhage, 1729), pp. 218-219; J.B. Descamps, Vie des peintres flamands, Allemands et Hollandais avec des portraits gravés en taille-douce, une indication de leurs principaux ouvrages, et des réflexions sur leur différentes manières, 4 vols., (Paris, 1753-1754), vol. 2, p. 367.

${ }^{4} \mathrm{E}$. Duverger and D. Maufort, "Nieuwe gegevens over de zeventiende-eeuwse Antwerpse kunstschilder Gijsbrecht Thijs (¿1617-1684?)", Gentse bijdragen tot de kunstgeschiedenis en oudheidkunde 31 (1996), p. 229-249.

$5 \mathrm{Ph}$. Rombouts and Th. van Lerius, De Liggeren en andere historische archieven der Antwerpse Sint Lucasgilde, 2 vols, (Anvers: Gravenhage, 1864-1876); 2 vols, (ed. Anvers/La Haye, De Sikkel, 1961), vol. 1, p. 419; Duverger and Maufort, "Nieuwe gegevens...", p. 230.

${ }^{6}$ E. Duverger \& D. Maufort, "Het Antwerps kunstenaarsgeslacht Tijssens (Thyssens) uit de zeventiende en het begin van de achttiende eeuw en zijn stamvader Augustijn Tijssnes de Oude", Gentse Bijdragen 31 (1996), p. 127.

7 Augustijn Tijssens was believed to be Peter Thys's father [Descamps, Vie des peintres..., vol. 4, p. 206]; a mistake corrected by Kramm, who provides biographical data [C. Kramm, De levens en werken der Hollandsche en Vlaamsche kunstschilders, beeldhouwers, graveurs en bouwmeesters, van den vroegsten tot op onzen tijd, V, Amsterdam, 1891, p. 652]. As a painter, in addition to works referred to in documents, a Landscape and a Vision of Saint-Norbertus by his workshop are known. He was also extremely active as an expert and art dealer (Duverger and Maufort, "Het Antwerps kunstenaarsgeslacht Tijssens...", pp. 141$147,150-157$, figs.).

${ }^{8}$ He was confused with a sculptor (Kramm 1891 (note 6), vol 7, p. 1653). Only four works by his hand are recorded in his brother's inventory (1675): "Eenem Verloren Sone, Een Fontain, Onse-Lieve Vrouw Boetschap, Een Groot Mariebelt o peen raem" (Duverger and Maufort 1996 (note 5), p. 160).

${ }^{9}$ See his works in Duverger and Maufort 1996 (note 5), pp. 160-181, figs. 4-15.

10 Duverger and Maufort 1996 (note 5), pp. 178-186.

${ }^{11}$ Antwerpen, Stadsarchief, Doopregister Sint-Jacobskerk, PR 48, fo 162 (Duverger and Maufort, "Nieuwe gegevens...", p. 232, no. 31).

12 "Geysberecht Teys, schilder, bey Jakes vanden Bemden (S

childer), g. 2.16" (Rombouts and Lerius, De Liggeren..., vol 2, pp. 4,7).
} 
We also know that at the age of twenty he was accepted into the guild as a master during the time that Gabriel Frank was Dean in 1636-3713, and that he soon became a member of the De Violieren rhetorical chamber when Joannes Galle was its dean $(1638)^{14}$. His annual contribution is recorded in the accounts of that society until the year $1646-47^{15}$. We know that Thys was in Italy, as the inventory compiled in 1650 on the death of his father, Artus Thys the Younger, states that Gysbrecht was in Rome ${ }^{16}$. He must have set out for Italy in or after 1647 and could have remained there until 1652 as in

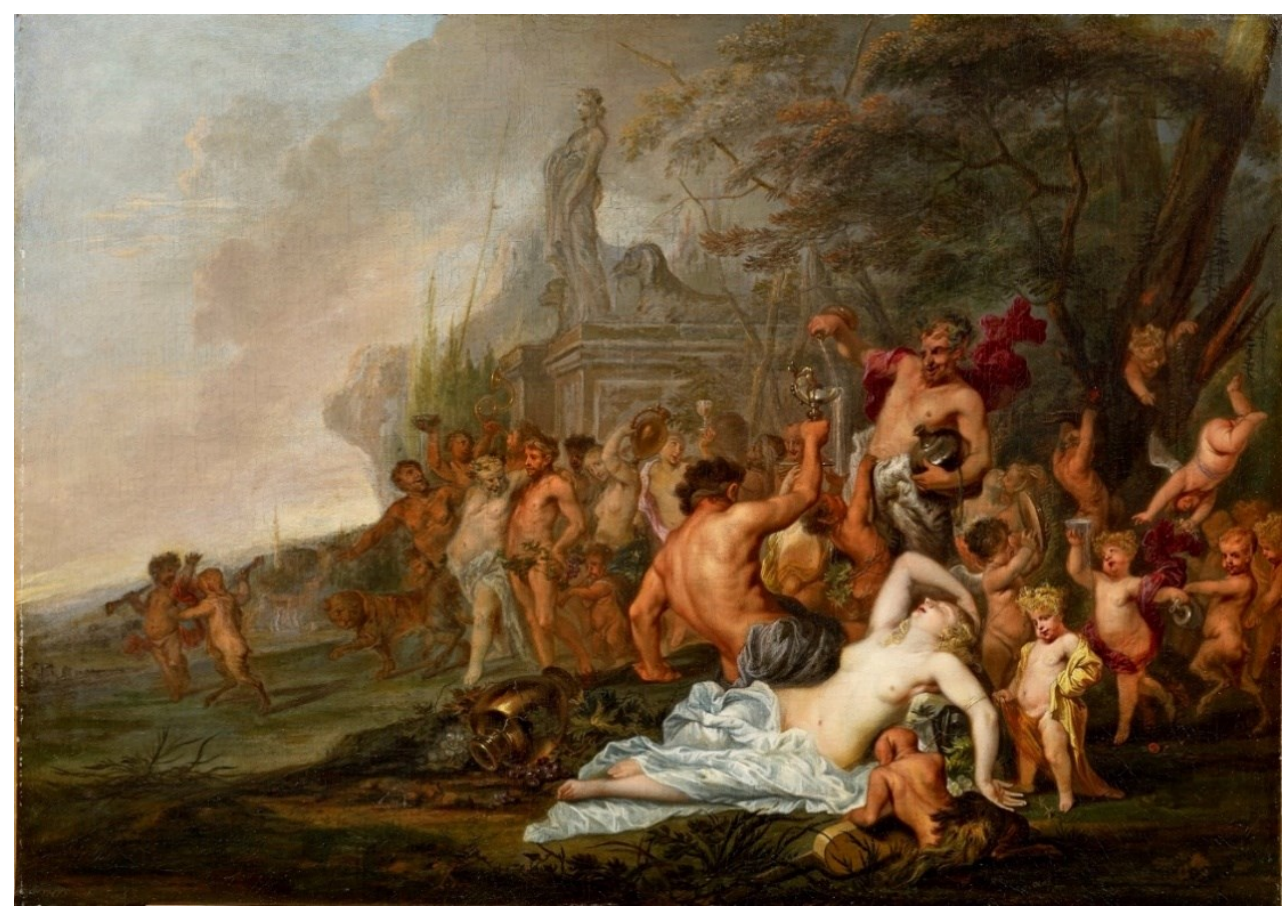

Fig. 1. Gysbrecht Thys, Bacchanal, Signed and dated “... THYS F. 1653” (bottom left), canvas, 52 x 73 cm. Present whereabouts unknown. (Photograph: Artcurial, Paris)

the latter year he married Catharina Lodewijcx in Antwerp. Their son Gysbrecht the Younger was born soon after.

Cornelis de Bie who seems to have known Gysbrecht Thys at first hand, refers to him as a specialist 'both in devotional painting and Poetries, but also in Landscape'17. Old inventories in Antwerp refer to Thys as the painter of an Europa, a Venus and Adonis, a Susanna, an Allegory, a Penitent Magdalene,

\footnotetext{
${ }^{13}$ Rombouts and Lerius, De Liggeren..., vol 2, pp. 81, 87.

14 "Anderen ontfanck van de nieu liefhebbers die onder my syn ingecomen: Gysbrecht Tys (shilder), 18 g." (Rombouts and Lerius, De Liggeren..., vol 2, p. 107). "Joannes Galle, Deken, A $^{\circ}$ 1638, onder de welcke inde Bloom als liefhebber ontfangen syn: Gysbrecht Thys, Baltesar Moerentorf, Adriaen van Thison, Abarham Vinck" (F. Donnet, "Het jonstich versaem der Violieren, geschiedenis der rederijkkamer de olijftak sedert 1480", Antwerpsche bibliophilen 23 (1907), p. 229, 231).

15 Rombouts and Lerius, De Liggeren..., vol. 2, pp. 126, 140, 149, 161, 184.

${ }^{16}$ E. Duverger, Antwerpse Kunstinventarissen uit de zeventiende eeuw. Fontes Historiae Artis Neerlandicae Bronnen voor de Kunstgeschiedenis van de Nederlanden, (Brussels, 1984-2004), vol. 6, p. 129.

17 "So in devotie als Poëtrijen, mede oock in Landtschap" (C. De Bie, Het gulden cabinet vande edel vry schilderconst, (Antwerpen, 1662), p. 412; Duverger and Maufort, "Nieuwe gegevens...", pp. 236-37).
} 
a Head of a Woman and other unspecified works ${ }^{18}$. In 1661 at the request of his lawyer, the Guild of Saint Luke was asked to value a Birth of Christ by his hand $^{19}$. In 1668 the accounts of the art dealer Guillam Forchondt refer to a Head by the artist ${ }^{20}$, a Pyramus and Thisbe which Forchondt sold in 1673 to Prince Karel of Liechtenstein ${ }^{21}$, and a painting with Sleeping young Women mentioned in invoices of 1690 and $1706^{22}$. Despite these documentary references, until recently no works by the artist's hand were known.

In 2014 a Bacchanal appeared on the Paris art market, signed and dated '[...] THYS F.1653' (fig. 1) ${ }^{23}$. Even if the initial of his first name remains illegible, the attribution to Gysbrecht Thys is convincing. The style of the Bacchanal is coherent with the rest of the works that will be discussed, and it corresponds well with the only surviving proof of Gysbrecht certain authorship: the interior of the Garland of fruit and flowers which is signed with the initial 'G. THYS' (fig. 8), which allows for an exclusion of his homonyms. The Bacchanal dates from after the artist's return from Italy, which largely explains the influences that it reveals. The bacchanalian procession is set in an Italianate landscape with a prominent statue of Venus; an elderly and inebriated Bacchus leads the retinue of dancing Sileni and nymphs. At the foot of a tree and surrounded by small satyrs in playful poses, a Silenus pours wine into a nautilus cup held by another Silenus who is seated behind a semi-nude nymph lying languidly asleep in the foreground. The Silenus' powerful torso recalls ancient sculptures like the famous Belvedere Torso (fig. 2) and the Dying Gaul (fig. 3) the latter leaning on his arm in the same position. The reclining nymph looks to Titian's Bacchanal of the Andrians (fig. 4) ${ }^{24}$, although differing in the location of the white cloth that covers her pubis and thighs and in the position of her left arm, which falls down towards the ground, suggesting her state of drunken abandon. An interesting demonstration of Thys' powers of naturalism and a detail absent in Titian's original is the way the skin of the nymph's armpit is depicted as creased due to the position of her arm and the weight of her body resting on

\footnotetext{
18 1678, Inv. Jan I Vermaes; SA, Notaris J. Lucas 2560 (1678), fo 11-13vo (J. Van den Branden, "Verzameling van schilderijen te Antwerpen", Antwerpsch Archievenblad 22 (1864), p. 3; J. Denucé, De Antwerpsche "Konstkamers. Inventarissen van kunstverzamelingen te Antwerpen in de 16 e en 17 e eeuwen, Bronnen voor de geschiedenis van de Vlaamsche kunst, 2, (Antwerpen, 1932), p. 270; Duverger, Antwerpse Kunstinventarissen..., vol. 10, p. 233). "Tysens (Gysbrecht). No 241. Une pièce représentant une Allégorie. H.11 pouc. L. 15 pouc. T.". 242. La Magadelaine en pénitence. H. 2 pieds. 1 pouce. L. 19 pouc. B. No 243. La tête d'une femme. H. 20 pouc. L. 1 1/2 pied. T." (Vente Jean-Baptiste du Bois, Gent [Pierre de Goesin], 21-9-1776). Two other paintings are registered in the inventory of Joanna Huijbrechts, widow of Melchior Bretson "[Kavel A] No 19. Van Ghijskens Thijs"; [Cavel E] No 22. Van Gijsken Thys" (Duverger, Antwerpse Kunstinventarissen..., vol. 11, pp. 299, 301).

19 "Op heden den 13 septembris 1661 ten versuecke van Mynheer Jacob Lasson is ter vergaderinge van de camer van Sint-Lucasgilde geprissert een stuc schildery Kertsnacht geschildert van Gijsbrecht Tys ter Somme van twintich guldens" (Antwerpen, Archief Sint-Lucasgilde, Resolutieboek der dekens en oudemannen van het Sint-Lucasgilde [1659-1727], no. 100; Duverger and Maufort, "Nieuwe gegevens...", p. 239, no. 72).

20 "Een troni van Gysken Tys" (J. Denucé, Kunstuitvoer in de 17de eeuw te Antwerpen. De Firma Fourchoudt, [Antwerpen, 1931], p. 99).

21 "Pyramus en Tisbe van Gijskens Tys" (Denucé, Kunstuitvoer..., pp. 136, 172).

22 "Slapende Vraukens van Gysken Tys" (Denucé, Kunstuitvoer..., pp. 234, 256).

23 Oil on canvas, $52 \times 73 \mathrm{~cm}$. Signed and dated "... THYS F. 1653" (bottom left). From a Belgian private collection. Paris (Artcurial), 26-3-2014, no. 121.

${ }^{24}$ Madrid, Museo del Prado. H. Wethey, The Paintings of Titian, 3 vols, London, 1969-1975, cat. no. 15.
} 
the stone. Thys emphasised the figure's sensuality, confirming Cornelis de Bie's opinion when he singled out the artist's talent for the nude.

It is very likely that Gysbrecht would have seen the celebrated ancient marbles in Rome, that were a widely used source for artists, including François Perrier who reproduces etchings of them in his famous compendium of antique sculptures published in Rome in 1645, shortly before Thys arrived $^{25}$. However, Thys could not have seen the original of Titian's Bacchanal, which left Italy in 1637 to enter the collection of Philip IV of Spain.

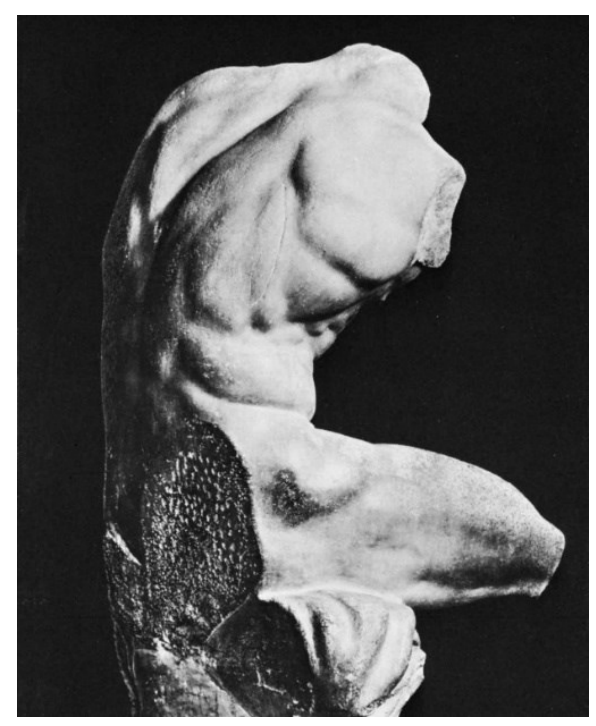

Fig. 2. Apollonios, son of Nestor, Athenian, Belvedere Torso, marble, Rome, Vatican Museums

It is likely that Gysbrecht would have taken the figure of the nymph from a copy of the painting that he could have seen in Italy or Flanders ${ }^{26}$, rather than through the widely known prints by Giovanni Andrea Podestà. Copies of Titian's Bacchanal include the one by Alessandro Varotari (Il Padovanino) in the Accademia Carrara in Bergamo, and the one by Rubens (Stockholm, Nationalmuseum), which remained in that artist's collection until his death in $1640^{27}$. Van Dyck reproduced it in his Italian sketchbook ${ }^{28}$ and also painted a small copy that entered the collection of Everhard Jabach $(1696)^{29}$; while Jan

\footnotetext{
25 On Goltzius's drawing, see E. K. J. Reznicek, Die Zeichnungen von Hendrick Goltzius, (Utrecht, 1961), I, p. 321 . On the one by Rubens, M. Van der Meulen, Rubens copies after the Antique, Corpus Rubenianum Ludwig Burchard, (Antwerpen, 1994), vol 2, p. 56, no. 37. François Perrier, Icones et segmenta illustrium e marmore tabularum quae Romae..., (Roma, 1645).

${ }^{26}$ Wethey, Titian..., vol. 3, p. 152.

$27 \mathrm{~J}$. Wood, Copies and Adaptations from Renaissance and later Artists: Italian Masters. Titian and North Italian Art, Corpus Rubenianum Ludwig Burchard, (Antwerpen, 2010), no. 118.

${ }^{28} \mathrm{G}$. Adriani, Anton van Dyck Italianisches Skizzenbuch, Vienna, 1940, fol. 56r; C. Brown, "Van Dyck and Titian", in Bacchanals by Titian and Rubens, Papers given at a symposium in the Nationalmuseum, (Stockholm, March 18-19, 1987), pp. 155-166.

29 The painting is described as follows in the 1696 inventory: "267. Bacchanal; sur le devant, une femme couchée, de son long, près d'une eau, la teste appuyée sur une urne; auprès d'elle un enfant qui pisse, avec quantité de figures, de Vandeck. 20 liv." (Mémoire de Tableaux et autres effects appartenent a deffunt noble homme Évrard Jabach, directeur de la Compagnie des Indes, et a Madame sa veuve, 17 Juillet 1696; in E.H. de Grouchy, "Everhard Jabach. Collectionneur parisien [1695]", Mémoires de la Société de I'Histoire
} 
van den Hoecke painted a now lost, large canvas that was in the collection of the Archduke Leopold Wilhelm of Austria in $1659^{30}$.

The style of this Bacchanal by Gysbrecht Thys recalls a Christ on the Cross I saw some years ago in a private collection in Madrid (fig. 5) ${ }^{31}$, which had a tentative attribution to Thomas Willeboirts Bosschaert that was not convin-

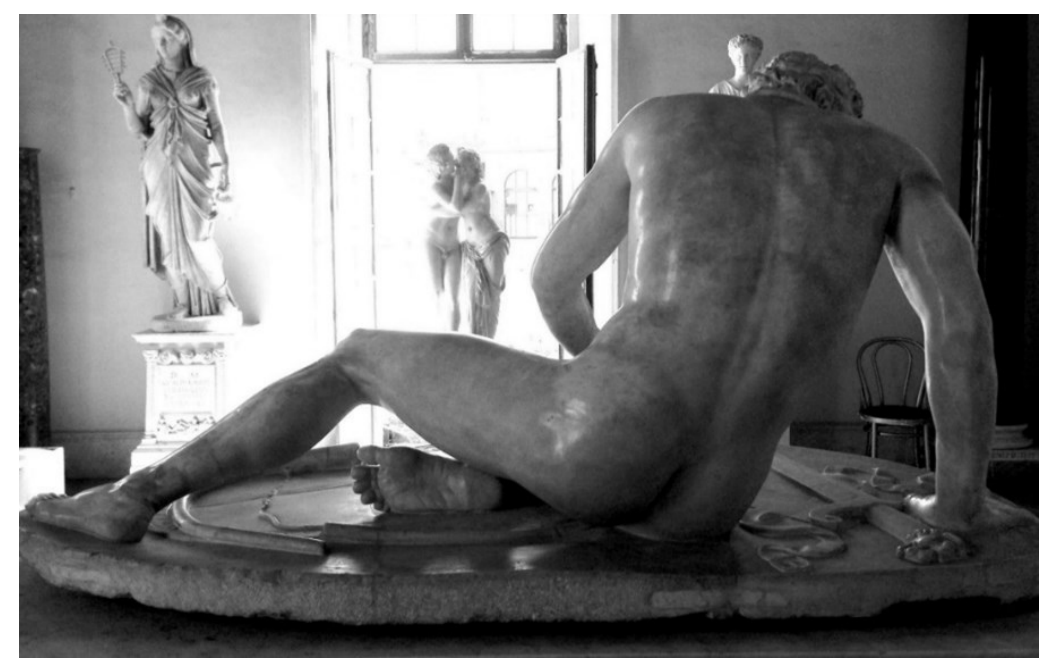

Fig. 3. Dying Gaul. Marble. Rome, Musei Capitolini.

(Photograph: Sovrintendenza Capitolina ai Beni Culturali, Rome)

cing. Christ is seen on the cross, in a solitary, low landscape with a cloudy sky. A circle of infant angels holds hands as they flutter gracefully around him, while another one flies straight down to take the martyr's crown and palm and a third (kneeling at the foot of the cross) looks up, drying his tears on his own drapery as he looks at the dead Christ. The composition is based on a skilfully conceived geometry in which diagonal lines prevail. Rather than opting for a frontal presentation of Christ, the artist depicts him foreshortened, receding into the pictorial space. The head hanging down and the closed eyes indicate that he has died, as narrated in the Gospel of Saint John. This type of composition is close to Van Dyck's in his Crucifixion for the

de Paris et de l'Ile de France 21 [1894], p. 264; F. Grossmann, "Holbein, Flemish Paintings and Everhard Jabach", The Burlington Magazine 93 [January 1951], p. 25).

30 Oil on canvas, $203,8 \times 210 \mathrm{~cm}$. Recorded in the Archduke Leopold-Wilhelm's inventory (1659) among the copies by Hoecke after Titian and Veronese ("Ein grosses Stuckh von Öhljarb auf Leinwaeth, warin das Bachanale von Titiano, welches der Johann von Hoeckh copyert). In einer ganz vergulden Ramen mit Oxenaugen hoch 9 Span 8 Finger und bräidt 10 Span 1Finger"; in A. Berger, "Inventar der Kunstsammlung des Erzherzogs Leopold Wilhelm von Osterreich", Jb. der Kunsthistorischen Sammlungen des Allerhöchsten Kaiserhauses I (1883), doc. 495, pp. 125, no. 9; J. Sanzsalazar, "Jan van den Hoecke: quelques précisions et nouvelles propositions pour le catalogue de son oeuvre", Revue Belge d'Archéologie et d'Histoire de I'Art, Académie Royale d'Archéologie de Belgique / Belgish tijdschrift voor Oudheidkunde en Kunstgeschiedenis, Koninklijke Academie voor Oudheidkunde van België LXXXII (2013), p. 65, no. 73.

${ }^{31}$ Oil on canvas, $72 \times 50 \mathrm{~cm}$. Acquired in Bordeaux (Bernard Venot Expert), 1991 (as anonymous). 
church of Sint-Rombouts in Malines, in turn inspired by Rubens's Coup de Lance, both reproduced as engravings by Schèlte à Bolswert ${ }^{32}$.

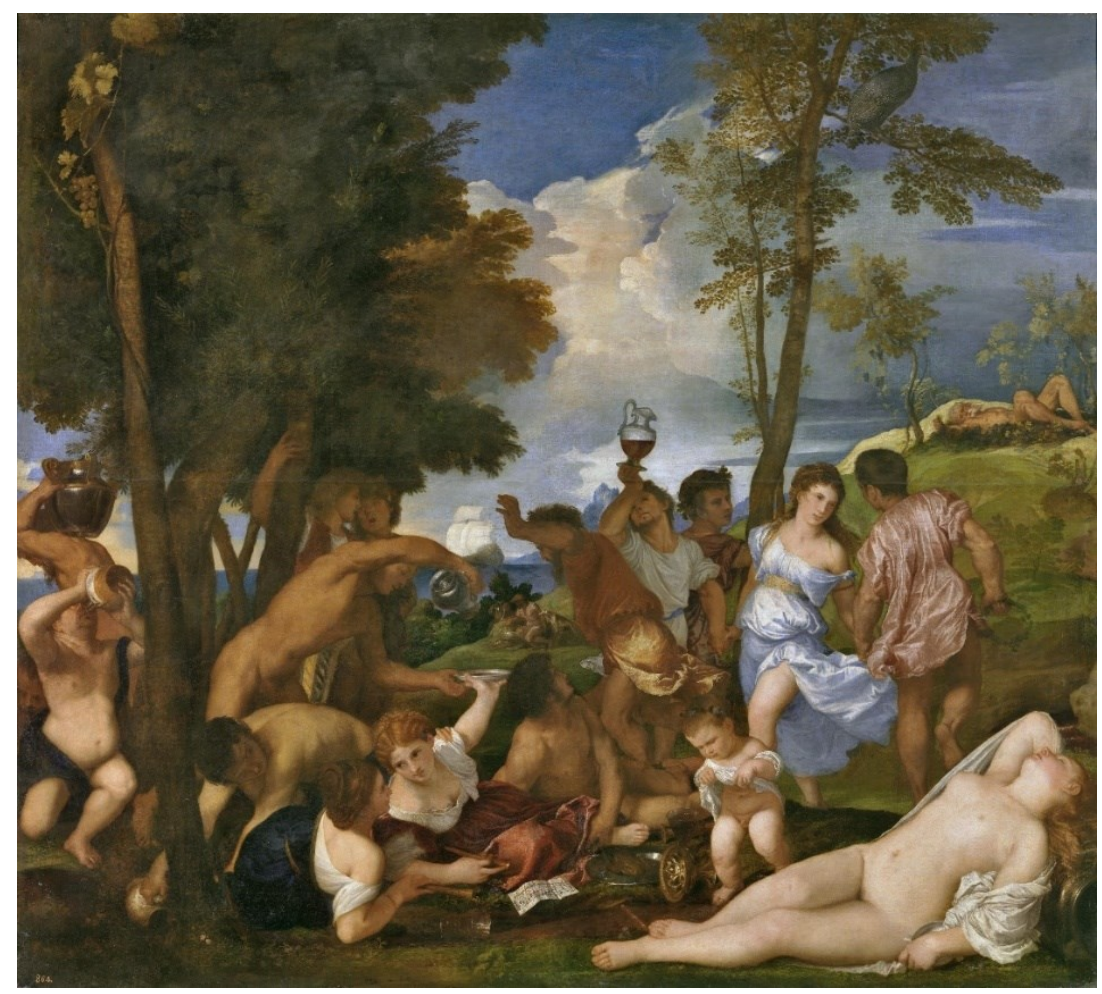

Fig. 4. Tiziano Vecellio called Titian, Bacchanal of the Andrians, c. 1523 - 1526, (oil on canvas, 175 x $193 \mathrm{~cm}$.), Museo del Prado (CMuseo Nacional del Prado)

Comparing that Christ on the Cross with the present Bacchanal, it is clear that various striking similarities suggest the same hand, notably a comparable approach to the landscape with the horizon line crossing the composition and ascending from left to right, the foreground left in chiaroscuro and the dry, broken branches of the vegetation which seem to be burned. The small angels are comparable in both works with regard to their visual dialogue and morphology: thick ankles, pointed feet, wings and the curls of their hair, moving in the wind and seemingly full of energy. The painter seems to delight in depicting the acrobatics of their little bodies animated by gushes of wind, whilst their hair is painted with an agitated brushstroke. The palette is also the same, notably the yellow colour of the drapery worn by a number of the figures in both paintings. This series of similarities suggests that the Crucifixion is by Gysbrecht Thys, and the question remains of whether or not it could be the unattributed "Cruijcefix"

32 The New Hollstein. Dutch \& Flemish Etchings, Engravings and Woodcuts 1450-1700, Anthony van Dyck, (Rotterdam, 2002), vol 7, 531. 
referred to in the inventory compiled on the death of the artist's father in $1650^{33}$.

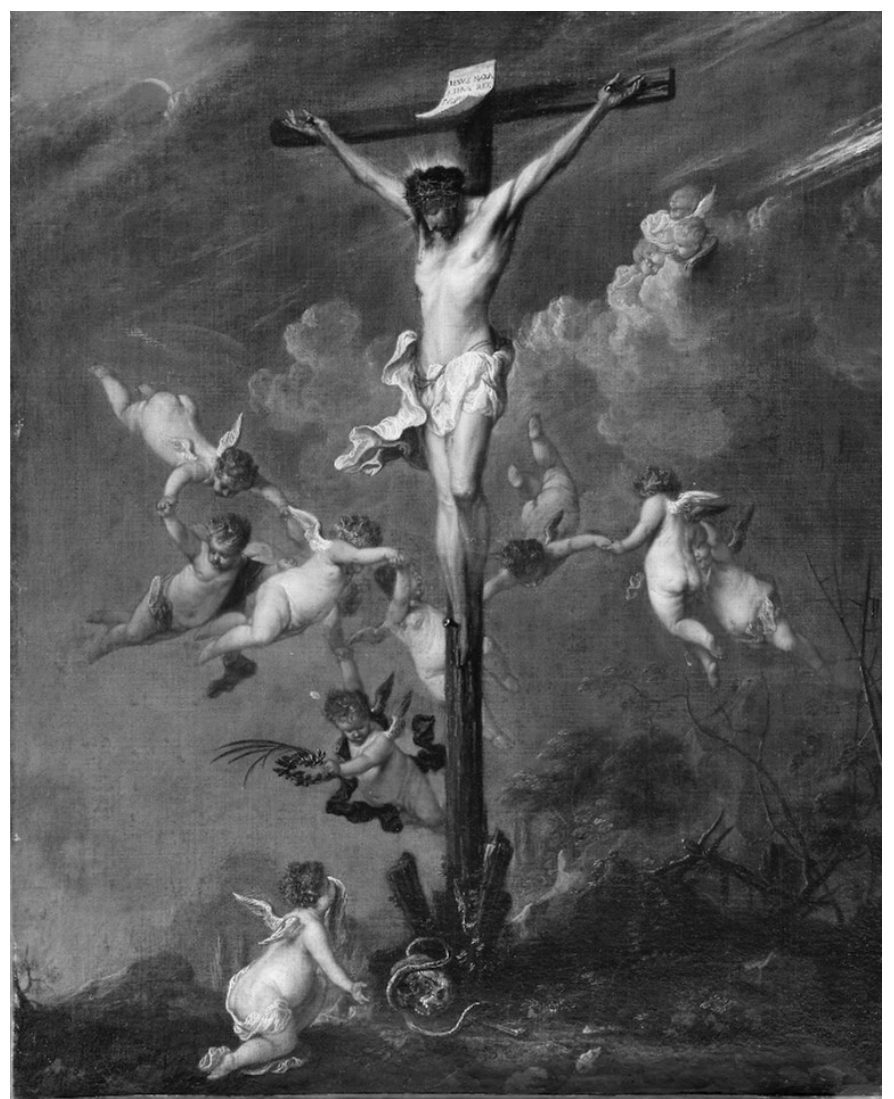

Fig. 5. (Here attributed to) Gysbrecht Thys, Christ on the Cross, (canvas, $72 \times 50 \mathrm{~cm}$.) Madrid, private collection (Photograph: Tomas Gaban, Madrid)

Some time ago I associated this Christ on the Cross with a Holy Family with Angels and a Monstrance with the Host in the Sint-Bartholomeuskerk in Merksem, near Antwerp (Fig. 6) ${ }^{34}$, in which I recognised the same hand but I was unable to relate it to any particular artist. That work, which is signed 'THYSSENS' and dated 1656, was attributed to Peter Thys until 1986 when Danielle Maufort correctly excluded it from his oeuvre given the lack of any characteristic stylistic traits ${ }^{35}$. Nothing was known of Gysbrecht Thys at that time, leading to doubts about the authenticity of the signature. It can now be confirmed that it clearly corresponds both technically and stylistically to the works discussed above.

\footnotetext{
33 "Een stuck schilderije wesende een Cruijcefix"; 1650, 3 Juli. Inventaar Artus I Thys, weduwnaar van Johanna Genoels en echtgenoot van Catharina van Everbroeck (SA. Notaris A. Van der Donck 3767 [1650], fo 5-8v; Duverger, Antwerpse Kunstinventarissen..., vol. 6, p. 130).

34 Oil on canvas, 57 x 115 cm. Merksem, Kerk Sint-Bartholomeus. Cliché kik-irpa: M087203. Fotorepertorium van het meubilair van de Belgische bedehuizen. Provincie Antwerpen. Kanton Merksem, (Brussels, 1976).

35 Maufort, De Antwerpsche kunstschilder Peeter Thijs..., p. 247, Cat. VR-21, pl. vxiv (as not by Peter Thys).
} 
A recognisable trait in the Holy Family is the interest in depicting the vegetation, as well as the same types of small angels, some of them literally repeated. The composition is similarly symmetrical, with the Holy Family loca-

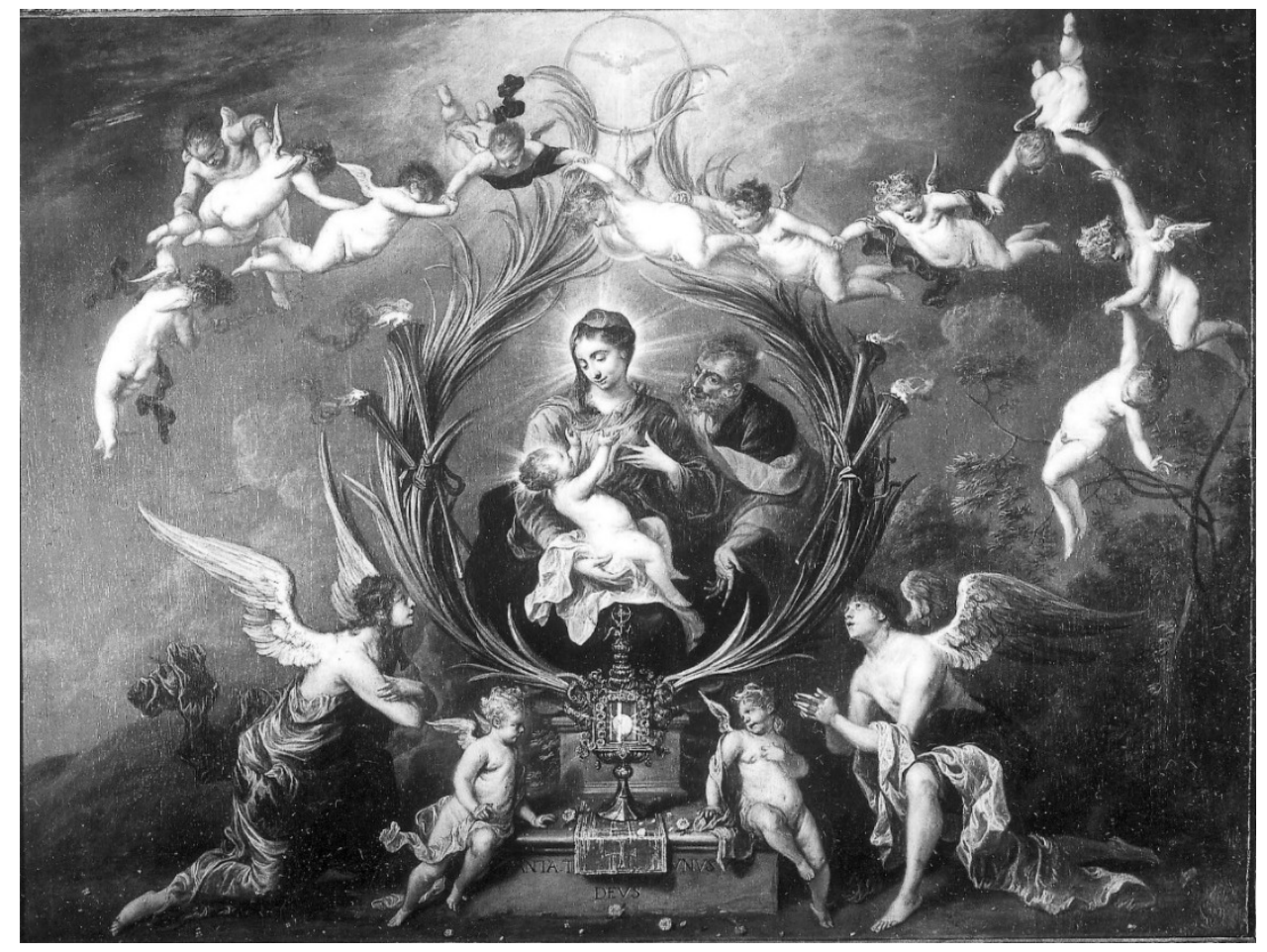

Fig. 6. (Here attributed to) Gysbrecht Thys. The Holy Family with Angels and a Monstrance with the Host, signed and dated: «THYSSENS, 1656 », (oil on canvas, 57 x $115 \mathrm{~cm}$.) Merksem, Kerk Sint-Bartholomeus (CKIK-IRPA,

Brussels)

ted in the centre of a garland of palms and flaming torches, around which flutter cherubim holding hands while two youthful angels kneel in prayer before a monstrance. At the top is the dove of the Holy Spirit, forming a vertical axis with the monstrance containing the Host. Carved on the stone pedestal is the inscription: 'SANTA T[RINITAS] VNVS / DEVS' [Holy Trinity, one God], which is the prayer of the Litanies of the Virgin.

Boethius used this phrase as the title for the first chapter of his philosophical treatise in which he defended the unity of the three holy figures as a single entity ${ }^{36}$. The same inscription can be found on a number of prints and paintings, in which the inscription is always associated with the three figures of the Holy Trinity: in the Otium Spirituale (Munich, 1617) after Raphael Sadeler ${ }^{37}$, in which God the Father holds the body of Christ on his lap, with the dove of the Holy Spirit above; in a print by Hieronymus Wierix

36 "TRINITAS VNVS DEVS AC NON TRES DII" (Boethius, Theological Tractates. Consolatio Philosophiae, chap. II).

${ }^{37}$ London, British Museum, Inv. 1878,0309.21. Amsterdam, Rijksmuseum, 90402. 
on the same subject ${ }^{38}$; and in a painting by the Valencian artist Joan de Joanes $^{39}$. In the present work it is also associated with the earthly Trinity, comprising the Virgin, Saint Joseph and the Christ Child, the link between the celestial and earthly realms and a reflection of the unity of the former, which was energetically defended by Francisco de Sales in his Conferencias espirituales. While the depiction of the two Trinities is common in $17^{\text {th }}$-century painting, it is normally depicted in a different manner, with Christ walking whilst holding his parents' hands under the protection of God the Father and the dove of the Holy Spirit.

Also unusual is the association between the two Trinities and a monstrance with the Host. It may be inspired by Ignatius of Loyola's Spiritual Diary, which emphasises the importance of the connection between the Trinity and the Eucharist, considering that the entire mystery of God is present in the Eucharistic mystery ${ }^{40}$. Similarly, for Saint John of the Cross, the Trinity manifests itself in the Eucharist ${ }^{41}$. The flaming torches in the garland in the present Holy Family again refer to the divine light that illuminates the Christian believer when celebrating the Eucharist, while also evoking the three theological Virtues which their light represents: Faith from their light, Charity from their heat and Hope from their flame rising up to the heavens. The association between these flaming torches and the Virgin is inspired by the writings of Thomas Aquinus in defence of the Eucharist; Mary is not only illuminated but also illuminates herself ${ }^{42}$. As the mother of Christ, she was considered the 'luminary of the enlightened Church of God' by Saint Buenaventura ${ }^{43}$ and the 'Temple of the Trinity' by Saint Catherine of Siena. The role of the Virgin in the mystery of the Trinity was defended in texts contemporary with this painting, such as those by Chrysanthus Solarius $(1645)^{44}$ and Father Riccardi, who describes ranks of angels celebrate the Trinity with their songs, in his Raggionamenti sopra le Litanie di nostra Signora of $1626^{45}$. In some respects, the complex iconography of this Holy Family recalls aspects of Raphael's Disputà in the Stanza della Segnatura in the Vatican. The lower part of the composition with the kneeling youthful

\footnotetext{
${ }^{38}$ L.J. Alvin, Catalogue raisonné de l'œuvre des trois frères Jean, Jérome \& Antoine Wierix, (Bruxelles, 1866), pp. 2-3, no. 6.

${ }^{39}$ F.B. Domenech, Joan de Joanes: una nueva visión del artista y su obra, Valencia, 2000, p. 120.

40 J.M. Faraone, La inhabitación trinitaria según San Juan de la Cruz, Analecta Gregoriana, (Roma, 2002), p. 173.

41 J.V. Rodríguez, "Evangelio mariano de San Juan de la Cruz", Ephemerides Mariologicae 40 (1990), pp. 9-57.

${ }^{42}$ Saint Thomas Aquinus, Opuscule 8, Salutionem angelicam.

43 "Maria illuminatrix" or "clarissima lucerna". Cit. Sancti Bonaventurae ex ordine minorum (...) Opera Sixti V. Pont. Max., Tomus decimustertius, (Venetiis: Ex Typographia Joan. Baptistae Albritii Hier, 1756), p. 271.

${ }^{44}$ R.P. D. Chrysanthi Solarii, Pentateuchus mortuorum in quo leges... quinque libris traduntur quibus ad celestes aedes evehuntur mortui..., (Patavii: typis P. Frambotti, 1645), p. 34.

45 The subject of his eighth reasoning: "(...) tutti gli ordini Angelici, m'insegna S. Chiesa, che non mai cessano di cantar il Trisagio, e celebrar il mistero della Trinità, \& Que laudant Angeli, atque Archageli, Cherubim, atq; Seraphim, qui non cessant clamare quotidie, una voce dicentes, ¿Sanctus, ¿Sanctus" (...) "Non ama ella sola, piu che tutta la Chiesa militante, ¿e tronfante insieme?" (Nicolo Riccardi, Raggionamenti sopra le Litanie di nostra Signora, [Venezia, 1626], pp. 107-110).
} 
angels seems to be inspired by the frontispiece of the Missale Romanum, published by the Oficina Plantiniana in 1612 (fig. 7) ${ }^{46}$.

The above analysis of these three works thus confirms Cornelis de Bie's observation that Gysbrecht Thys specialised 'both in devotional painting and Poetries, but also in Landscape.' He also produced works of other types, for

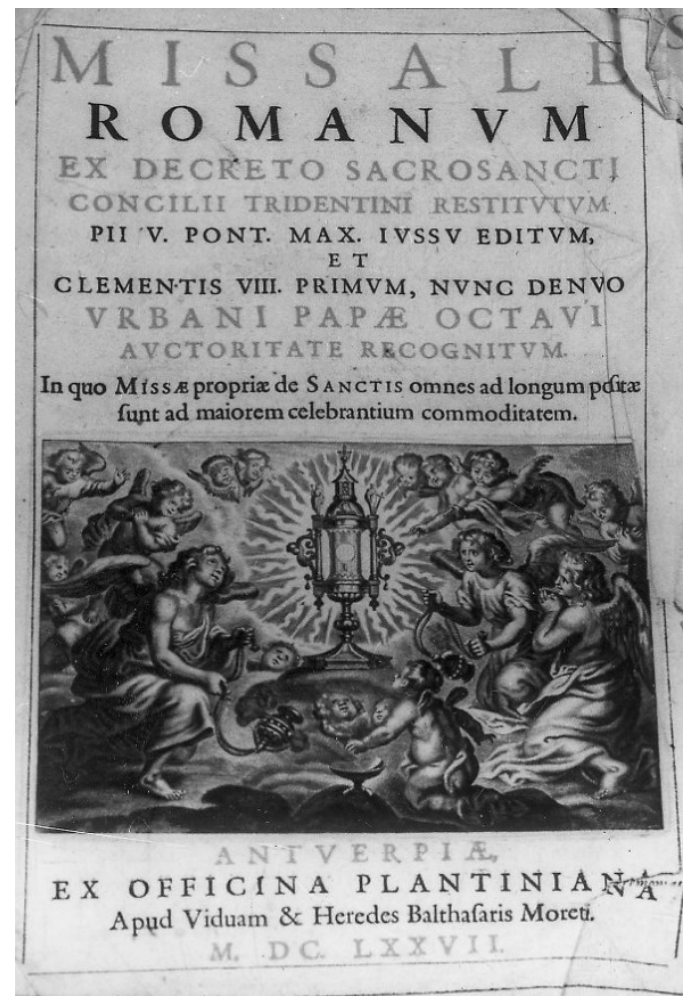

Fig. 7. Missale Romanum, Antverpiae, Ex. Officina Plantiniana, M. DC. LXXVII. Munte, Kerk Sint-Bonifatius.

(C) KIK-IRPA, Brussels)

example the Garland of Fruit and Flowers, co-executed with Joris van Son (Antwerp, 1623-1667), for which Thys painted the Virgin and Child with the infant John the Baptist as the central image (fig. 8) ${ }^{47}$. Both artists signed the painting, which was unusual in artistic collaborations of this type ${ }^{48}$. By virtue of Gysbrecht's initial in his signature; the interior of the Garland is the only surviving proof of his certain authorship. As a consequence, it becomes a key work for the further identification of partially signed or unsigned works, on the basis of stylistic evidence.

\footnotetext{
46 Missale Romanvm ex decreto Sacrosancti CConcilii Tridentini Constitutum, Pii V. Pont... Max. iussu editum et Clementis VII. Autoritatem recognitum, (Antverpiae: Ex Officina Plantiniana, Apud Vidiam et fillios Io. Moretti, 1612). A copy in the library of Sarnen Benediktinerkollegium, Switzerland (Sign. A/1b 214). The 1677 issue illustrated here is in Munte, Belgium, Kerk Sint-Bonifatius; cliché kik-irpa M257379. 47 Oil on canvas, $84.5 \times 62.3 \mathrm{~cm}$. Signed « G. THYS 》 (centre) and « J. VAN SON » (lower left). Paris (Christie's), 30-3-2015, no 22; Paris, private collection.

${ }^{48}$ Only one other example is recorded within Joris van Son's production: a Garland, with the interior signed "E.Q." (Erasmus Quellinus). This was attributed to Daniel Seghers until cleaning revealed the signature and date: "J. Van Son 1652" (M.L. Hairs, "Collaborations dans des tableaux de fleurs flamands", Revue belge d'archéologie et d'Histoire de l'Art 26 [1957], pp. 149-162).
} 
Still lifes of this type, which reached their peak in the Low Countries in the $17^{\text {th }}$ century, were the result of collaboration between two artists who combined their talents to achieve the best results. The garland was generally painted first and there are numerous examples in which they were never filled $\mathrm{in}^{49}$. The second artist would then paint a religious or secular image in grisaille

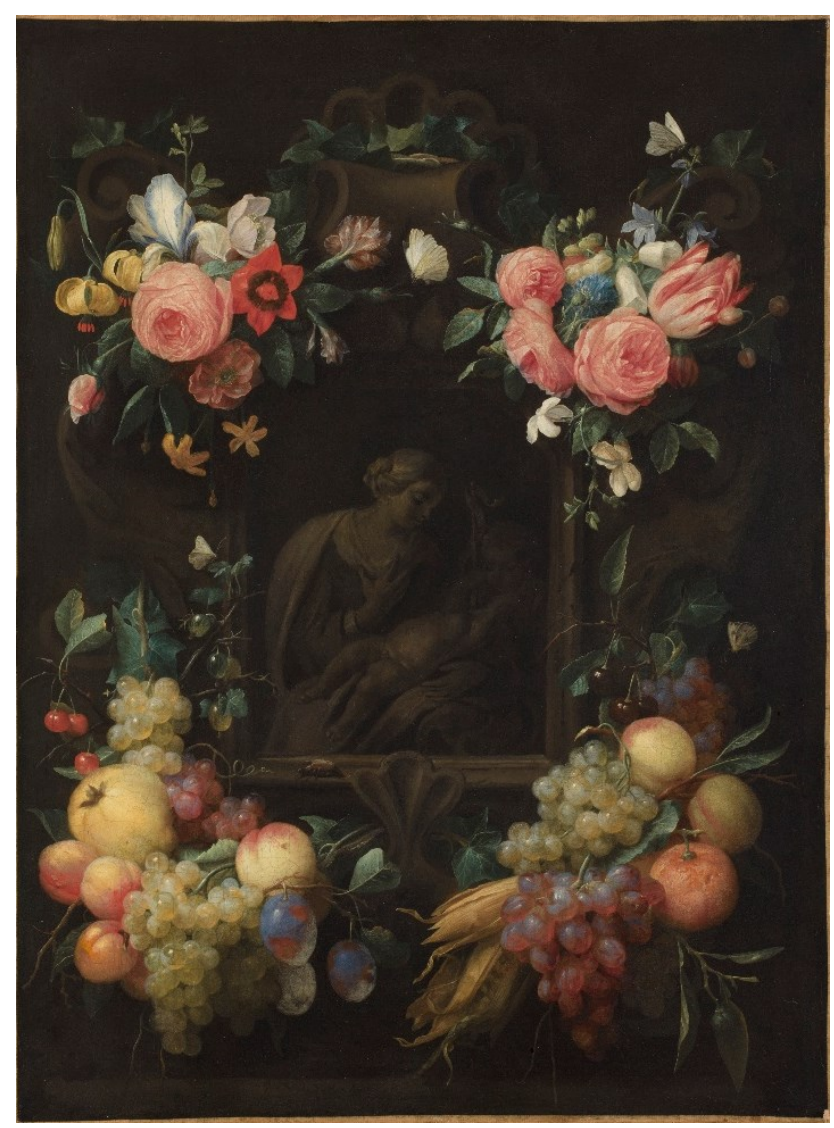

Fig. 8. Gysbrecht Thys and Joris van Son, The Virgin and Child with little saint John in a garland of fruits and flowers, signed: “G.THYS" (centre) and "J.VAN SON" (lower left) (canvas, 84,5 x 64,3 cn.), Paris, private collection (Photograph: Thomas Clot, Paris)

inside the garland, in the manner of trompe I'oeil sculpture. This genre was particularly disseminated by the Jesuit painter Daniel Seghers and was also used by leading names such as Rubens and Jan Brueghel. Highly symbolic in nature, these garlands refer to the concept of the Vanitas in a reflection of Ecclesiastes in the Old Testament. With their inevitably transient, perishable beauty, fruit and flowers represent the transitory nature of life, while roses evoke the Marian virtues of the Song of Songs. Saint Ambrose associated the beetle with Christ, an idea revived in the $17^{\text {th }}$ century by the Jesuit scholar Athanasius Kircher (1602-1680). Butterflies are a symbol of the human soul, evoking the cycle of life, death and resurrection.

\footnotetext{
${ }^{49}$ By Joris van Son, see for instance Cluster of oranges, lemons, pears, figs and other fruit, corncobs and nuts decorating a stone cartouche. Oil on canvas. $118 \times 101.5 \mathrm{~cm}$. Signed and dated: "J. VAN. SON. f1661". London (Christie's), 10-7-1998, no. 170.
} 
All these elements were painted with the admirable botanical and zoological accuracy characteristic of the northern still-life painters, while also possessing the symbolic connotations habitual in works of this type. The present work has all the hallmarks of Joris van Son's style: the careful handling, muted colour, unemphatic outlines which give the forms a spongy heaviness, and

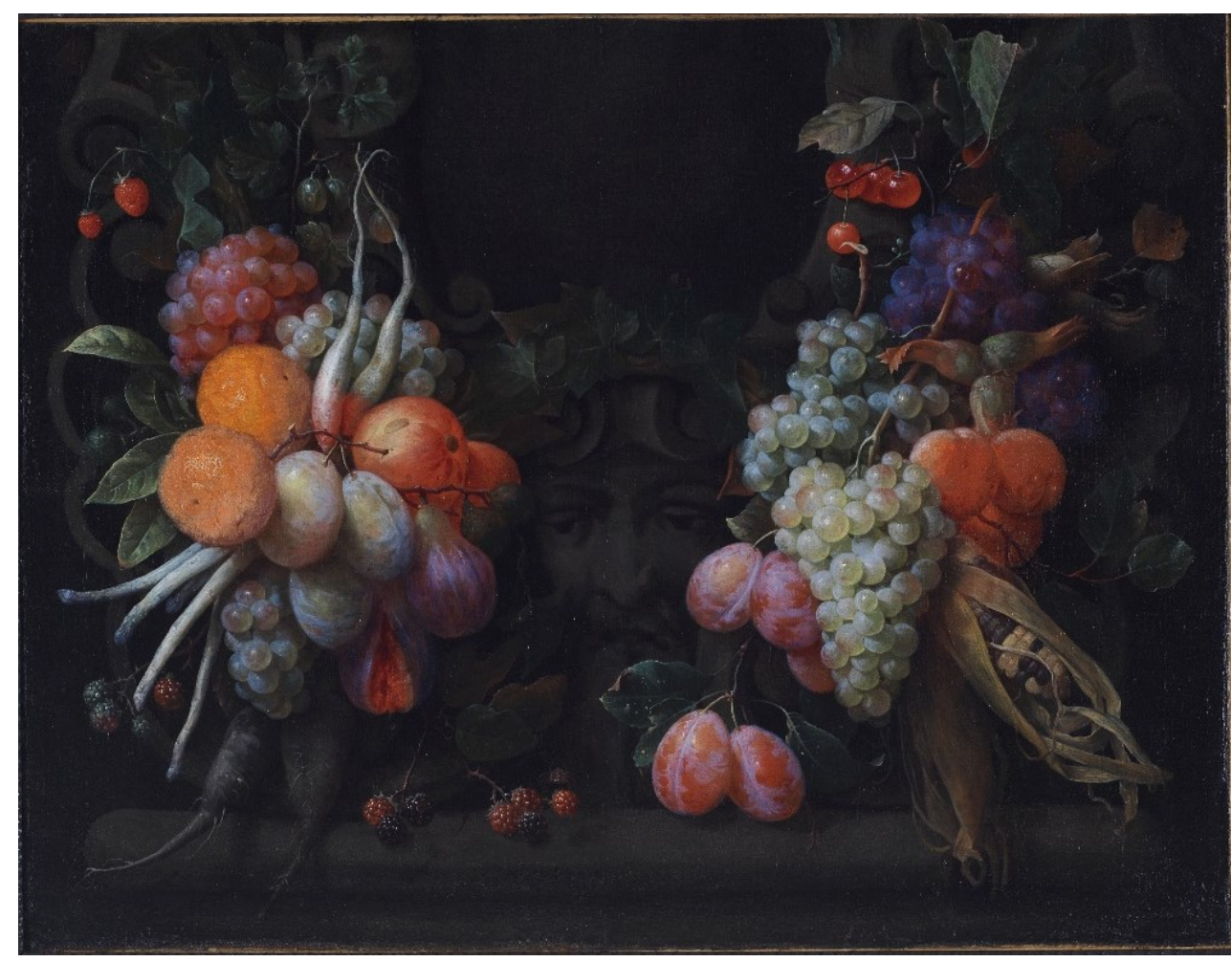

Fig. 9. Joris van Son, Garland of Fruit and Vegetable, signed and indistinctly dated "VAN SON f 16...", Epiarte collection (CPhotograph: Epiarte)

the soft hairiness of the surface of the pieces of fruit that creates a peachlike texture. Again, in a typical manner, the artist organises the elements into three groups to create triangular volumetric clusters, painting each group as if it were a separate still life. This undoubtedly facilitated dividing some of these works into separate compositions in order to make them more marketable. An example of the latter is the Garland of Fruit and Vegetables in Epiarte collection (fig. 9) ${ }^{50}$, which was the lower part of a larger composition. Fortunately, the artist's signature survives on this fragment. Its delicate handling, arrangement of the elements and choice of motifs are all comparable to the present Garland.

The flowers in the present work are located at the upper corners of the trompe l'oeil central panel with pieces of fruit at the lower ones. A similar

50 Oil on canvas, $51.1 \times 65.3 \mathrm{~cm}$. Signed and indistinctly dated: "VAN SON f 16...". London, Christie's 137-1945, no. 89; Northwick Park, Blockley, Collection Captain Edward George Spencer-Churchill (1876 1964); His sale, London (Christie's), 29-10-1965, no. 59; London (Sotheby's), 3-7-1985, no. 67; London (Christie's), 7-12-2005, no. 137; London (Sotheby's), 9-12-2010, no. 150; Barcelona, private collection. Lit. E.G.S. Churchill, The Northwick rescues, Northwick Park, 1961, no. 59. 
arrangement is to be seen in three Garlands (Museum Boymans van Beuningen, Rotterdam; Staatliche Museen, Schwerin; and on the art market), of which one is dated $1657^{51}$, providing a chronological guide to compositional arrangements of this type. Van Son's later garlands are more elaborate, for example, the canvas in the National Gallery of Denmark, Copenhagen, which is signed and dated $1665^{52}$.

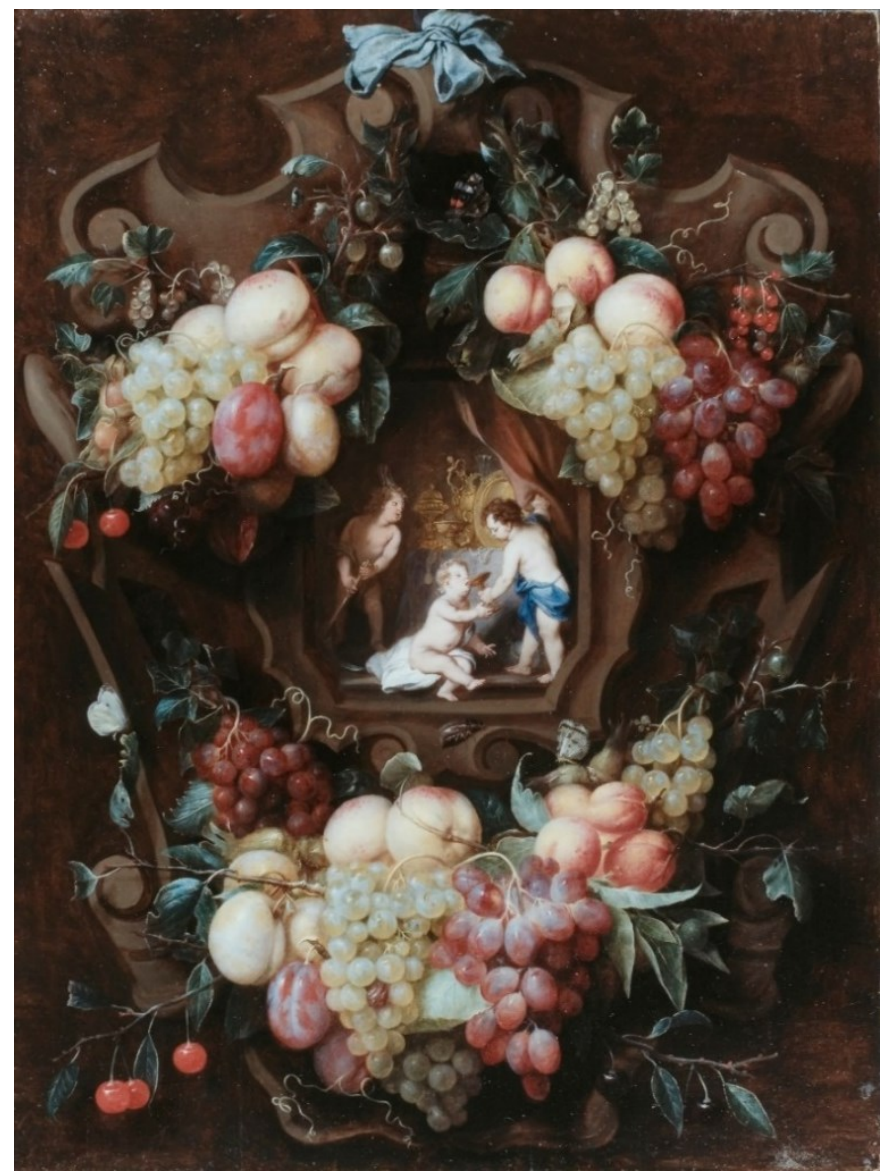

Fig. 10. (Here attributed to) Joris van Son and Jan van Balen (?), Garland of Fruit and Flowers with three Putti, traces of a signature (bottom left), (panel, 86 x $64 \mathrm{~cm}$.) Present whereabouts unknown (Photograph: 2016 Webwinkel RKD, Den Haag)

Van Son used a variety of techniques depending on the effect desired in the different areas of the composition. He conveyed the wrinkled texture of the orange with light impasto and the transparency of the grapes, cherries and plums by applying superimposed glazes. Here he probably used the technique found on a canvas at the Walters Art Gallery, which was the subject of pigment analyses during its restoration ${ }^{53}$. Those analyses revealed a double preparatory layer: a first layer of medium thickness and of a reddishbrown colour; and a second thinner layer applied over that (carbon with a

\footnotetext{
${ }^{51}$ Oil on canvas, $69.3 \times 53.5 \mathrm{~cm}$. Signed: "J. Van Son". Amsterdam (Christie's), 1-11-2011, no. 122.

52 Oil on canvas, $170 \times 121 \mathrm{~cm}$. Signed: "J. van. son. f1665". Copenhagen, National Gallery of Denmark, inv./cat.nr KMSsp289.

${ }^{53}$ R. Seidler, "A Still-Life by Joris van Son", The Journal of the Walters Art Gallery 47 (1989), pp. 91-97.
} 
small amount of earth pigments) that has a greyish tone which directly influenced the final result. The grey-brown tone of the background was added next, leaving the areas intended for the fruit and flowers unpainted as these were applied directly over the second, greyish preparatory layer. Other elements were painted over the greyish background to create an effect of chiaroscuro. For the veins of the leaves, Van Son scraped the still wet paint then applied another layer once it had dried, defining these elements by means of transparency.

Although Van Son's compositions and floral elements are often considered to be influenced by Jan Davidsz. de Heem and Frans Snyders, more evident here is the influence of Daniel Seghers and the impact upon his follower Jan Pauwel Gillemans, particularly the latter's Garland with the Image of the Virgin lactans of $1664^{54}$. In 1935 a work by Van Son of similar size and technique was referred to as in the Landoy-Strauss collection in Antwerp (Garland of Fruit and Flowers with the Virgin and Child) ${ }^{55}$. Nothing further is known of it but it might perhaps be identified with the present work.

A comparable composition is that of a Garland of Fruit and Flowers with the Bust of Seneca, signed 'J.VAN.SON.f', with a similar display of bouquets that does not achieve the same exquisite quality ${ }^{56}$. It remains unclear which artist painted the central image of the philosopher as little is identified of Van Son's collaborators, of whom the best known was Erasmus Quellinus ${ }^{57}$, giving rise to some unconvincing attributions ${ }^{58}$. An unreliable attribution to Van Son and Honthorst of a 'Bacchus and Ceres with Venus and Cupid in the distance' appears in the inventory of the collection of Thomas Loridon de Ghellinck in Ghent (1821), a painting that was attributed earlier in the $19^{\text {th }}$ century to Van Son and Jan Boeckhorst ${ }^{59}$. Old inventories in Antwerp, which include references to numerous works by Van Son, have not clarified this issue. Nonetheless, the fact that some of his works were in the collections of the painters Victor Wolfvoet (1652) ${ }^{60}$ and Jan van Balen (1654) ${ }^{61}$ warrants further associations. It has also been suggested that Frans Wouters collaborated on

\footnotetext{
54 Oil on canvas, $89 \times 67.5 \mathrm{~cm}$. "JP. Gillemans fecit 1664". Vienna (Dorotheum) 30-3-2000, no. 143.

55 Oil on canvas, $83 \times 56 \mathrm{~cm}$; 29/30-4-1935 (cf. Hofstede de Grootfiches, RKD, Den Haag).

56 Oil on canvas, $65 \times 51 \mathrm{~cm}$. De Vuyst (Lokeren) 06-3-1999, no. 417; Venduehuis der Notarissen (The Hague), 29-4-2015, no. 179. photo RKD 56621. It could also be the painting described as follows: "Grisaille vorstellende een Keizerbuste omgeven door vier vruchten-groepen, bestaande uit pruimen, citroenen, kersen en mandarijnen. Doek H. 66, B. 50. Voluit geteekend", Amsterdam (Mak van Waay), 15/17-101935 , no. 45

57 J.-P. De Bruyn, "Samenwerking van de Rubensepigoon Erasmus II Quellinus (1607-1678) met de vruchtenschilder Joris van Son (1623-1667)", Jaarboek van het Koninklijk Museum voor Schone Kunsten Antwerpen (1979), pp. 281-294.

${ }^{58}$ Quellinus's collaboration is not convincing in the Garland of Fruit with a Portrait of two Boys oil on canvas, signed and dated: "J. VAN SON. F. / 1637". Prague, Narodni Galerie, inv. nr 1700 (See L. Slavicek, in Das Flämische Stilleben, 1550-1580, exhib. cat. Vienna/ 2002, p. 342, no. 120). The interior of the composition has been attributed to Van Son in H. Vlieghe, "Flemish Still-Life Painting. Vienna and Essen", The Burlington Magazine 145 (Feb. 2003), p. 115.

59 Goesin-Verhaeghe, de Porre \& Verhulst, September 1821, no. 242 (as Joris van Son and Honthorst); Gent (Fernand), 23-7-1804, no. 94 (as Joris van Son and Jan Boeckhorst).

60 "No 2. Een stuck van Joris van Son wesende van Fruyten in lyste panneel; (...) No 375. Een Bancketken van Van Son op panneel in lystken" (1652. Inv. Victor Wolfvoet, in zijn woning overleden in de SintJanstraat; in Duverger, Antwerpse Kunstinventarissen..., vol. 6, p. 343, 354).

61 "Een stuck van Bloemen van Joannes Son op doeck in lyste" (1654. Inventaris van de nagletan goederen van Jan van Balen; in Duverger, Antwerpse Kunstinventarissen..., vol. 7, p. 30).
} 
the Garland of Fruit and Flowers with three Putti (Fig. 10) ${ }^{62}$. I would propose instead Jan van Balen (1611-1654), in comparison with a Garland that he signed with Jean Philip van Thielen in 1650 (Fig. 11) ${ }^{63}$; a work that will prove significant to the construction to Jan van Balen's work. Furthermore, it points

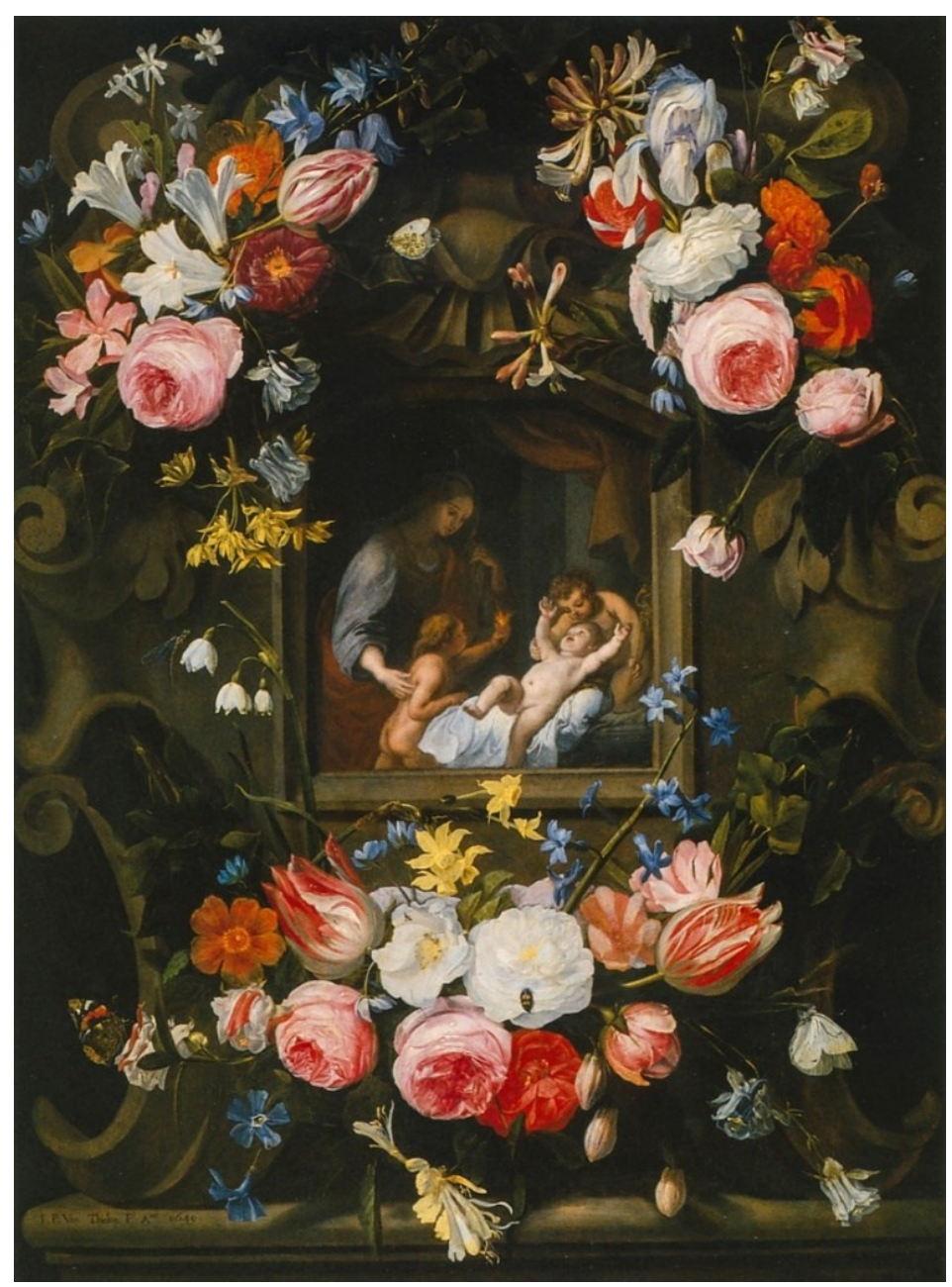

Fig. 11. Jan Philip van Thielen and Jan van Balen, Virgin and an angel offering a flaming heart to the Infant Christ on a cartouche decorated with bouquets of flowers, signed and dated, «I.P.Thielen F. An. 1649» and «J. van Balen F. 1650»Present whereabouts unknown (Photograph: 2016 Webwinkel rkd, Den Haag)

to artistic connections with Gysbrecht Thys that could be a consequence of Gysbrecht's uncle Joost having trained at Hendrick van Balen's studio in 1602. Gysbrecht Thys and Jan van Balen chose a very similar position of the Child in his mother's lap, lying face up, his arms raised and his head tilted back to touch his cousin's face. The arching of the Child's back is more exaggerated

62 Oil on panel, $86 \times 64 \mathrm{~cm}$. Traces of a signature (bottom left): "J...". Amsterdam/London, with art dealer Gebr. Douwes, shown in Maastricht (TEFAF), 2003-2005; Amsterdam (Glerum Auctioneers), 13-11-2005, no. 31; Lille (Mercier \& Cie), 26-3-2006, no. 198; Köln (Lempertz), 15-5- 2010, no. 1670.

63 The Virgin and an angel offering a flaming heart to the Infant Christ on a cartouche decorated with bouquets of flowers, signed and dated «I. P. Thielen F. An 1649 », and « J. van Balen F. 1650 ». Oil on panel, 86.3 x $63.3 \mathrm{~cm}$. London (Christie's), 12-4-1985, no. 143 ; London (Christie's), 22-4-1988, no. 45 ; Maastricht, European Fine Art Sale, 1991 ; Paris (Chayette) 12-2-1996, no. 26. 
and particularly well resolved in Gysbrecht's depiction. The position may derive from Ruben's compositions engraved by Schèlte à Bolswert published by Cornelis Galle $\mathrm{II}^{64}$. The Virgin's pose, her hand on her breast as she looks tenderly at the Child, recalls poses by Van Dyck, particularly the Virgin in The Rest on the Flight into Egypt in the Royal Collection, for which the grisaille version painted for reproduction as a print was in Antwerp ${ }^{65}$. In turn, Van Dyck's image derives from models by Titian such as The Virgin with the Christ Child and Saints (Kunsthistorisches Museum, Vienna), which Thys could have copied in Italy, as Van Dyck did in his Italian sketchbook ${ }^{66}$.

In the case of the present Garland, the presence of the signatures ']. van Son' and 'G. THYS' prove this previously unknown collaboration, filling a gap in the output of this 'Peintre Excellent en fruits, fleurs, \&c,' whom Cornelis de Bie compared to the sun in a wordplay on his name ('Zon' or Sun in Dutch) ${ }^{67}$ and who would be influential for future generations of painters ${ }^{68}$. This invaluable piece of evidence should help to identify other collaborators of Joris van Son. A Bacchus and Ceres in a Garland of Fruit and Flowers ${ }^{69}$ and a Drunken Bacchus and Satyrs in a Garland of Fruit and Flowers, signed ']. van Son. $1654^{\prime}$ deserve further study ${ }^{70}$.

Knowledge of this collaborative facet of Thys's work allows us to start to define the artistic personality of a previously forgotten painter. From the works published in this text, Gysbrecht Thys appears as a more versatile painter than expected after Cornelis de Bie's report. He must have assimilated a degree of classical culture in Italy that is evident in his secular paintings, combined with the tradition of Van Dyck and Rubens and the influence of Titian. The complex iconography of his devotional paintings suggests that he was associated with erudite religious circles and allows us to see him as the continuer of a type of art that disseminated the dogmas of the Counter Reformation. It would be interesting to know the appearance of the Europa, Venus and Adonis, Susanna, Allegory, Penitent Magdalene and Head of a Woman and other works attributed to him in old inventories, and it can only be hoped that more paintings by his hand will appear.

\footnotetext{
${ }^{64}$ Hollstein's Dutch and Flemish Etchings, Engravings and Woodcuts ca. 1450-1700, 60-149.

65 Panel, 38.4 x 32.4 cm. A. Balis, "Van Dyck: Some Problems of Attribution," in: Van Dyck 350, S. J. Barnes and A.K. JR. Wheelock (ed.), (Washington and Hanover, 1994), p. 192 (as by Van Diepenbeeck, although not seen at first hand); S. Barnes, O. Millar, N. de Poorter and H. Vey, Van Dyck: A Complete Catalogue of the Paintings, (New Haven and London 2004), pp. 253-254, under no. III.10 (tending towards the attribution to Van Diepenbeeck); M. Díaz Padrón, J. Sanzsalazar and A. Diéguez, Van Dyck en España, (Barcelona, 2012), vol. 2, p. 692, no. A. 18 (Abraham van Diepenbeeck after van Dyck); New York (Christie's), 26-1-2012, no. 26 (as Van Dyck).

${ }^{66}$ M. Jaffé, The Devonshire Collection of Northern European Drawings, (London, 2002), p. 80, no. 1107, $11 \mathrm{~V}$.

67 M. L. Hairs, Les peintres flamands de fleurs au XVIIe siècle, (Bruxelles, 1965), pp. 275-277.

${ }^{68}$ A. P. de Mirimonde, "Une Guirnalde de fruits par T. Smith au Musée de Gray", Oud Holland 72 (1957), pp. 53-56.

${ }_{69}$ Oil on canvas, $92 \times 70 \mathrm{~cm}$. Signed: "Joris Van". Vienna (Dorotheum), 21-3-2002, no. 29.

70 Oil on canvas, $107 \times 80.5 \mathrm{~cm}$. Nice (Wetterwald-Rannou-Cassegrain), 2-12-2006, no. 8.
} 
Bibliography:

Adriani 1940: Gert Adriani, Anton van Dyck Italianisches Skizzenbuch, (Wien, 1940).

Alvin 1886: Louis Joseph Alvin, Catalogue raisonné de l'œuvre des trois frères Jean, Jérome \& Antoine Wierix, (Bruxelles, 1866).

Aquinus: Saint Thomas Aquinus, Opuscule 8, Salutionem angelicam.

Balis 1990: Arnout Balis, "Pieter Thys, Marten Pepyn und der dritte "PseudoBoeckhorst"', in Jan Boeckhorst, Maler der Rubenszeit, (Freren, 1990), pp. 98-108.

Balis 1994: Arnout Balis, "Van Dyck: Some Problems of Attribution," in Van Dyck 350, S. J. Barnes and A.K. JR. Wheelock (ed.), (Washington and Hanover, 1994), pp. 177-196.

Barnes et al. 2004: Susan Barnes, Oliver Millar, Nora de Poorter and Horst Vey, Van Dyck: A Complete Catalogue of the Paintings, (New Haven and London, 2004).

Berger 1883: Adolf Berger, "Inventar der Kunstsammlung des Erzherzogs Leopold Wilhelm von Osterreich", Jahrbuch der Kunsthistorischen Sammlungen des Allerhöchsten Kaiserhauses I (1883), pp. LXXXIX-CLXXVII.

Boethius, Anicius Manlius Severinus Boëthius, Theological Tractates. Consolatio Philosophiae, chap. II.

Bonaventura: Sancti Bonaventurae ex ordine minorum (...) Opera Sixti V. Pont. Max., Tomus decimustertius, (Venetiis: Ex Typographia Joan. Baptistae Albritii Hier, 1756).

Brown 1987: Christopher Brown, "Van Dyck and Titian", in Bacchanals by Titian and Rubens, Papers given at a symposium in the Nationalmuseum, (Stockholm, March 18-19, 1987), pp. 155-166.

Bruyn 1979: Jean Pierre de Bruyn, "Samenwerking van de Rubensepigoon Erasmus II Quellinus (1607-1678) met de vruchtenschilder Joris van Son (1623-1667)", Jaarboek van het Koninklijk Museum voor Schone Kunsten Antwerpen (1979), pp. 281-294.

Churchill 1961: Edward George Spencer Churchill, The Northwick rescues 1912 - 1961, (Northwick Park, 1961).

De Bie 1662: Cornelis de Bie, Het gulden cabinet vande edel vry schilderconst, (Antwerpen, 1662).

De Gelder y Vander Motten 2009: Katrien Daemen-de Gelder and Jean Pierre Vander Motten, "Peeter Thijs (1624-77) - an Antwerp Portraitist under the 
Patronage of William Frederick of Nassau-Dietz (1613-64", Zeitschrift für Kunstgeschichte 72 (2009), pp. 128-131.

Denucé 1931: Jan Denucé, Kunstuitvoer in de 17de eeuw te Antwerpen. De Firma Fourchoudt, (Antwerpen, 1931).

Denucé 1932: Jan Denucé, De Antwerpsche "Konstkamers. Inventarissen van kunstverzamelingen te Antwerpen in de 16 e en 17 e eeuwen, Bronnen voor de geschiedenis van de Vlaamsche kunst, 2, (Antwerpen, 1932).

Descamps 1753-1754: Jean Baptiste Descamps, Vie des peintres flamands, Allemands et Hollandais avec des portraits gravés en taille-douce, une indication de leurs principaux ouvrages, et des réflexions sur leur différentes manières, 4 vols., (Paris, 1753-1754).

Díaz Padrón et al. 2012: Matías Díaz Padrón, Jahel Sanzsalazar and Ana Diéguez, Van Dyck en España, (Barcelona, 2012), 2 vols.

Domenech 2000: Fernando Benito Domenech, Joan de Joanes: una nueva visión del artista y su obra, (Valencia, 2000).

Donnet 1907: Fernand Donnet, Het jonstich versaem der Violieren, geschiedenis der rederijkkamer de olijftak sedert 1480, Antwerpsche bibliophilen 23, (Antwerpen, 1907).

Duverger 1984-2004: Erik Duverger, Antwerpse Kunstinventarissen uit de zeventiende eeuw. Fontes Historiae Artis Neerlandicae Bronnen voor de Kunstgeschiedenis van de Nederlanden, (Brussels, 1984-2004), 13 vols.

Duverger and Maufort 1996: Erik Duverger and Danielle Maufort, "Het Antwerps kunstenaarsgeslacht Tijssens (Thyssens) uit de zeventiende en het begin van de achttiende eeuw en zijn stamvader Augustijn Tijssnes de Oude", Gentse Bijdragen 31 (1996), pp. 178-186.

Duverger and Maufort 1996: Erik Duverger and Danielle Maufort, "Nieuwe gegevens over de zeventiende-eeuwse Antwerpse kunstschilder Gijsbrecht Thijs (1617-1684?)", Gentse bijdragen tot de kunstgeschiedenis en oudheidkunde 31 (1996), p. 229-249.

Faraone 2002: José Mario Faraone, La inhabitación trinitaria según San Juan de la Cruz, Analecta Gregoriana, (Roma, 2002).

Fotorepertorium van het meubilair van de Belgische bedehuizen. Provincie Antwerpen. Kanton Merksem, (Brussels, 1976).

Grossmann 1951: Fritz Grossmann, "Holbein, Flemish Paintings and Everhard Jabach", The Burlington Magazine 93, (January 1951), pp. 16-25.

Grouchy 1894: Vicomte E.H. de Grouchy, "Everhard Jabach. Collectionneur parisien (1695)", Mémoires de la Société de l'Histoire de Paris et de I'Ile de France 21 (1894).

Hairs 1957: Marie Louise Hairs, "Collaborations dans des tableaux de fleurs flamands", Revue belge d'archéologie et d'Histoire de l'Art 26 (1957), pp. 149-162. 
Hairs 1965: Marie Louise Hairs, Les peintres flamands de fleurs au XVIIe siècle, (Bruxelles, 1965).

Hairs 1977: Marie Louise Hairs, Dans le sillage de Rubens: les peintres d'histoire anversois au XVIIe siècle, (Liège, 1977).

Hollstein 2002: VVAA, The New Hollstein. Dutch \& Flemish Etchings, Engravings and Woodcuts 1450-1700, Anthony van Dyck, Rotterdam, 2002.

Houbraken 1719: Arnold Houbraken, De groote schouburgh der Nederlantsche konstschilders en schilderessen, (Den Haag, 1719), 2 vols.

Jaffé 2002: Michael Jaffé, The Devonshire Collection of Northern European Drawings, (London, 2002).

Kramm 1891: Christiaan Kramm, De levens en werken der Hollandsche en Vlaamsche kunstschilders, beeldhouwers, graveurs en bouwmeesters, van den vroegsten tot op onzen tijd, V, (Amsterdam, 1891).

Maufort 1986: Danielle Maufort, De Antwerpsche kunstschilder Peeter Thijs de Oude. Een enadering aan de hand van zjn historiestukken, Verhandeling van licenciaat, prom. H. Vlieghe, (Leuven, Katholieke Universiteit, 1986).

Maufort 1994-1995: Danielle Maufort, "Een zelfportret van Peter Thijs de Oude (1624-1677) in de Koninklijke Musea voor Schone Kunsten van België", Bulletin Koninklijke Musea voor schone Kunsten van België, (1994/1-4 1995/1-4), pp. 103-124.

Maufort 2001: Danielle Maufort, "Une Vanité avec les trois Parques au Musée d'Art et d'Histoire de Genève et l'oeuvre du peintre anversois Peter Thijs (1624-1677)", Genava 49 (2001), pp. 3-15.

Mirimonde 1957: Albert Pomme de Mirimonde, "Une Guirnalde de fruits par T. Smith au Musée de Gray", Oud Holland 72 (1957), pp. 53-56.

Missale Romanvm ex decreto Sacrosancti Concilii Tridentini Constitutum, Pii V. Pont... Max. iussu editum et Clementis VII. Autoritatem recognitum, (Antverpiae: Ex Officina Plantiniana, Apud Vidiam et fillios Io. Moretti, 1612).

Perrier 1645: François Perrier, Icones et segmenta illustrium e marmore tabularum quae Romae adhuc extant a Francisco Perrier delineata, incisa et ad antiquam formam lapideis exemplaribus passim collapsis restituta..., (Roma, 1645).

Reznicek 1994: Emil Karel Josef Reznicek, Die Zeichnungen von Hendrick Goltzius, (Utrecht, 1961).

Riccardi 1626: Nicolo Riccardi, Raggionamenti sopra le Litanie di nostra Signora, (Venezia, 1626).

Rodríguez 1990: José Vicente Rodríguez, "Evangelio mariano de San Juan de la Cruz", Ephemerides Mariologicae 40 (1990), pp. 9-57. 
Rombouts \& Lerius 1864-1876: Philip Rombouts and Theodoor van Lerius, De Liggeren en andere historische archieven der Antwerpse Sint Lucasgilde, 2 vols, Anvers / 's Gravenhage, 1864-1876; 2 vols, éd. Anvers/La Haye, De Sikkel, 1961.

Sanzsalazar 2009: Jahel Sanzsalazar, "Una nueva pintura de Peter Thijs identificada en la colegiata de Santa Gertrudis de Nivelles (Valonia)", Archivo Español de Arte 82 (2009), no. 325, pp. 79-86.

Sanzsalazar 2010: Jahel Sanzsalazar, "Peter Thijs: A preparatory drawing identified for The marthyrdom of saint Benedict with saint Felix of Cantalice", Delineavit et Sculpsit 33 (July 2010), pp. 25-29.

Sanzsalazar 2013: Jahel Sanzsalazar, "Jan van den Hoecke: quelques précisions et nouvelles propositions pour le catalogue de son oeuvre", Revue Belge d'Archéologie et d'Histoire de l'Art, Académie Royale d'Archéologie de Belgique, LXXXII (2013), pp. 45-78.

Seidler 1989: Ruth Seidler, "A Still-Life by Joris van Son", The Journal of the Walters Art Gallery 47 (1989), pp. 91-97.

Slavicek 2002: Lubomír Slavicek, in Das Flämische Stilleben, 1550-1580, exhib. cat. (Vienna, 2002).

Solarii 1645: R.P. D. Chrysanthi Solarii, Pentateuchus mortuorum in quo leges... quinque libris traduntur quibus ad celestes aedes evehuntur mortui..., (Patavii: typis P. Frambotti, 1645).

Stewart 1997 : J. Douglas Stewart, "Pieter Thys (1624-1677). Recovering a scarcely known Antwerp painter", Apollo (Feb. 1997), pp. 37-43.

Stewart 2001: J. Douglas Stewart, "Thomas Willeboirts Bosschaert and Pieter Thys: a tale of two tangled Antwerp painters; with an Excursus on Van Dyck's St. Felix of Cantalice", in Van Dyck 1599-1999: Conjectures and Refutations, H. Vlieghe (ed.), (Brussels, 2001), pp. 271-288.

Tomić 1995: Radoslav Tomić, "Prijedlog za Pietera Thysa: «Pranje nogu u Bribiru », Peristil, Zbornik radova za poviejest umjetnosti 38 (1995), pp. 117120.

Van den Branden 1864: Joos van den Branden, "Verzameling van schilderijen te Antwerpen", Antwerpsch Archievenblad 22 (Antwerpen, 1864).

Van der Meulen 1994: Marjon Van der Meulen, Rubens copies after the Antique, Corpus Rubenianum Ludwig Burchard, (Antwerpen, 1994).

Vlieghe 1994: Hans Vlieghe, "Thoughts on Van Dyck's Early Fame and Influence in Flanders", in Van Dyck 350, Studies in the History of Art, Center for Advanced Study in the Visual Arts, Susan J. Barnes and Arthur K. Wheelock (ed.), vol. 46, (Washington, 1994), pp. 211-215.

Wethey 1969-1975: Harold Wethey, The Paintings of Titian, (London, 19691975), 3 vols. 
Weyerman 1729: Jacob Campo Weyerman, De levens beschrijvingen der Nederlandse konstchilders en konst-schilderessen..., (Gravenhage, 1729).

Wood 2010: Jeremy Wood, Copies and Adaptations from Renaissance and later Artists: Italian Masters. Titian and North Italian Art, Corpus Rubenianum Ludwig Burchard, (Antwerpen, 2010).

Recibido: 29/08/2017 Aceptado: $30 / 10 / 2017$ 